\title{
Ovarian clear cell carcinoma meets metabolism; HNF-1ß confers survival benefits through the Warburg effect and ROS reduction
}

\author{
Masaki Mandai ${ }^{1,2}$, Yasuaki Amano${ }^{1}$, Ken Yamaguchi ${ }^{1}$, Noriomi Matsumura1 ${ }^{1}$ Tsukasa \\ Baba $^{1}$ and Ikuo Konishi ${ }^{1}$ \\ ${ }^{1}$ Department of Gynecology and Obstetrics, Kyoto University Graduate School of Medicine, Kyoto, Japan \\ ${ }^{2}$ Department of Obstetrics and Gynecology, Kinki University Faculty of Medicine, Osaka-Sayama, Japan \\ Correspondence to: Masaki Mandai, email: mandai@kuhp.kyoto-u.ac.jp \\ Keywords: ovarian clear cell carcinoma (OCCC), HNFI B, cancer-specific metabolism, oxidative stress, Warburg effect \\ Received: June 29, $2015 \quad$ Accepted: August 10, $2015 \quad$ Published: August 31, 2015
}

This is an open-access article distributed under the terms of the Creative Commons Attribution License, which permits unrestricted use, distribution, and reproduction in any medium, provided the original author and source are credited.

\section{ABSTRACT}

Ovarian clear cell carcinoma (OCCC) constitutes one of the subtypes of ovarian cancers, but it has unique clinical, histological and biological characteristics, one of which is chemo-resistance. It is also known to develop from endometriotic cyst, a benign ovarian tumor, at relatively high frequency. Recently, it is becoming well known that most of OCCCs express HNF1ß, a transcription factor, which is closely associated with the development of liver, pancreas and kidney, as well as occurrence of familial forms of type 2 diabetes. Expression of HNF1 $\beta$ is now regarded as a hallmark of this tumor. Nevertheless, exact biological function of this gene in OcCC has not been clarified. We have shown in previous studies that microenvironment in endometriotic cysts contains severe oxidative stress and OCCC develops under such stressful environment as stress-resistant tumor, which may lead to chemo-resistance. We also showed that increased expression of HNF1 $\beta$ facilitates glucose uptake and glycolysis, which is known as Warburg effect. In the previous issue of this journal, by using comprehensive metabolome analysis, we report that HNF1 $\beta$ actually reduces and protects themselves from internal oxidative stress by dramatically changing cellular metabolism. In this article, we review the relevance and significance of cancer-specific metabolism and how they are associated with biological characteristics of OCCC via expression of HNF1 $\beta$, along with future clinical implications of targeting cancer-specific metabolism.

\section{INTRODUCTION}

Ovarian clear cell carcinoma (OCCC) has recently been considered as a distinct entity among epithelial ovarian cancers. While a majority of the epithelial cancers are relatively sensitive to chemotherapy, OCCCs are mostly chemo-resistant [1-4], and a novel therapeutic approach is urgently desired. Other notable features that distinguish this tumor from other subtypes includes frequent occurrence in endometriotic cysts, relatively slow growth, and frequent complication of thromboembolism [4-7]. In particular, the vast majority of cancers arising in endometriotic cysts are either clear cell or endometrioid subtype, suggesting that a unique carcinogenic process is involved [8-10].
Nevertheless, the underlying mechanisms to explain the uniqueness of OCCC are not fully understood, partly because specific genetic events associated with OCCC had not been clarified. However, recently, genetic events including the ARID1 A mutation [11-13], activation of the PIK3A mutations $[14,15]$ and hepatocyte nuclear factor $1 \beta$ (HNF1 $\beta$ ) overexpression [16-18] have been linked to OCCC. We have been continuously investigating the causal relationship between the microenvironment in the endometriotic cyst and the occurrence of OCCC from various viewpoints $[8,10,19,20]$. Recently, we have shown that HNF $1 \beta$ overexpression significantly influences the metabolic activity of OCCC, which is distinct from that of other ovarian cancers [21]. It has also been suggested that altered metabolism caused by HNF $1 \beta$ overexpression 
in OCCC is responsible for some of the biological features of OCCC [22]. In this review, we provide an overview of cancer-specific metabolism, discuss how they play important roles in OCCC, and possible future direction of metabolism-targeted cancer therapy.

\section{MALIGNANT TUMOR EXHIBITS UNIQUE METABOLISM, CALLED WARBURG EFFECT}

It has long been recognized that cancer cells have unique, somehow curious metabolic features. In 1924, Otto Warburg reported that cancer cells, unlike most normal cells, prefer to metabolize glucose by glycolysis rather than oxidative phosphorylation, even in the presence of a sufficient oxygen supply that enables cells to perform the latter $[22,23]$. Energy production by glycolysis is far less efficient than by oxidative phosphorylation; only 2 ATPs per glucose versus 36 ATPs, respectively, are required [23]. This paradoxical phenomenon is called the "the Warburg effect". The Warburg effect, which is manifested by increased glucose consumption, decreased oxidative phosphorylation and accompanying lactate production, has been confirmed and is generally accepted as it has been demonstrated in various tumors. It is presently considered to be a metabolic hallmark of cancer [24-26]. This nature of cancers is clinically used as FDG-PET (F-fluoro2-deoxy-D glucose positron emission tomography) in various cancers including ovarian cancer. It has been reported that tumor metabolic activity is associated with prognosis of the patient with ovarian cancers in general [27] and OCCC [28], although the latter was reported to have lower FDG uptake compared with serous ovarian cancers [29]. However, the causal mechanism and implication for cancer biology still remains unclear.

Recently, several mechanisms have been proposed for the altered metabolism in cancer cells. First, specific genetic events were linked to the change in their metabolic status. In glioblastoma cells, inhibition of $\mathrm{H}-\mathrm{Ras}$ resulted in diminished glycolysis and cell death [30]. The oncogenic molecule Akt also stimulates aerobic glycolysis in cancer cells [31]. C-Myc potently enhances the glycolytic pathway, increasing target gene expression from glucose transporters through pyruvate kinase $[32,33]$. Mutation of the p53 tumor suppressor causes increased glucose consumption by enhancing the pentose phosphate pathway [34]. Therefore, transformation caused by oncogenes often accompanies the alteration of glucose metabolism. Second, the tumor microenvironment sometimes provides pressure for metabolic change, as shown in next section.

\section{MICROENVIRONMENT-ASSOCIATED GENE INDUCTION IN OCCC INCLUDES HNF1B}

It is clinically well known that OCCC arises predominantly from ovarian endometriotic cyst, which is characterized by repeated bleeding into the cyst cavity during the menstrual cycle [10]. We have shown that the content of an endometriotic cyst, consisting of old blood, which contains a markedly high concentration of free iron compared with other benign ovarian cysts [19]. Free iron is a source of reactive oxygen species (ROS) and is associated with cancer development through the induction of persistent oxidative stress in several organs, such as the liver and lung [35-37]. In fact, we have found that the level of oxidative stress and the extent of DNA damage were significantly elevated in endometriotic cysts [19]. These data indicate that 1) extensive oxidative stress in the endometriotic cyst may contributes to high incidence of cancer occurrence (Figure 1), and endometriotic epithelial cells which are exposed to extensive oxidative stress must cope with it to survive.

To further investigate the role of microenvironment in OCCC, we employed comprehensive gene-expression analyses. Microarray analysis identified a gene signature that distinguishes clear cell carcinoma from other types of ovarian cancer, which we designated as the ovarian clear cell carcinoma signature (OCCC signature) [20]. Importantly, the OCCC signature was induced when ovarian epithelial cells were exposed to the contents of endometriotic cysts, implying that it is originally driven by the unique microenvironment. A categorical analysis demonstrated that the OCCC signature is mainly comprised of genes belonging to three categories, stress response, sugar metabolism and coagulation, suggesting that these three entities define the biological identity of OCCC.

Among the genes included in the OCCC signature, we focused on HNF1 $\beta$ for the following reasons. First, HNF1 $\beta$ is overexpressed in the majority of OCCC. [16-18]. Due to its sensitivity and specificity, HNF1 $\beta$ overexpression is regarded as a hallmark of OCCC among epithelial ovarian cancers. Second, we have shown that the expression of HNF1 $\beta$ is epigenetically regulated [20, $38,39]$. In comparison of methylation profiles between OCCC and non-clear cell ovarian cancers, a majority of the OCCC-specific hypomethylated genes were shown to have HNF1-binding sites. Third, a pathway analysis of the OCCC signature suggested that HNF1 $\beta$ is a central mediator of the OCCC-specific signaling network [20]. Finally, a motif analysis revealed that HNF1 binding motifs are significantly enriched in genes that comprise the OCCC signature [18]. Collectively, we assumed that HNF $1 \beta$ plays a central role in the manifestation of the unique biological phenotype of OCCC. 


\section{HNF1B IS A KEY FACTOR BOTH IN ORGAN DEVELOPMENT AND CANCER OCCURRENCE}

HNF $1 \beta$ is a multifunctional transcription factor that shares strong homology with HNF1 $\alpha$ and regulates wide variety of gene expressions [40]. It is especially associated with the developmental process of important organs. HNF1 genes were originally identified as genes preferentially expressed in hepatocytes, and the lack of HNF1 $\beta$ lead to defective hepatic bud formation [41]. Additionally, the lack of HNF $1 \beta$ in mice leads to pancreas agenesis [42]. Maestro et al. suggested that HNF1 $\beta$ is a regulator of pancreas organogenesis and differentiation [43]. HNF $1 \beta$ was also shown to be essential for nephron segmentation during nephrogenesis [44]. Clinically, heterozygous germline mutations in HNF1 $\beta$ cause familial forms of type 2 diabetes called as maturity-onset diabetes of the young, subtype 5 (MODY5), which is frequently associated with congenital abnormalities, such as polycystic kidney, pancreatic hypoplasia and genital tract abnormality [45-47]. Mutations of HNF1 $\beta$ may also be responsible for some sporadic congenital renal abnormalities [48]. In adulthood homeostasis, HNF1 $\beta$ was shown to play a crucial role in renal repair after ischemia/ reperfusion in the acute kidney injury model $[49,50]$.

Contrary to the developmental stage in which
HNF1 $\beta$ defect influences normal organ development, overexpression of HNF $1 \beta$ has been reported in multiple malignancies. As stated above, it is specifically expressed in OCCC among ovarian cancers [16-18]. In addition, HNF1 $\beta$ may play an important role in prostate and hepatocellular carcinomas [51-53]. However, the precise mechanism of how HNF1 $\beta$ contributes to cancer biology remains unclear. So far, the reported function of HNF $1 \beta$ includes epithelial morphogenesis and differentiation [54, 55], regulation of the urate transporter and organic anion transporters [56, 57], and the metabolic regulation and ROS reduction discussed here.

\section{HNF1B DRASTICALLY ALTERS GLYCOLYTIC PROCESS IN OCCC CELLS}

The importance of the metabolic aspect of OCCC was predicted as stated above. In addition, there was growing evidence suggesting that HNF $1 \beta$ is associated with glucose metabolism. Balakrishnan et al. and our group reported that HNF1 $\beta$ induces sodium-glucose cotransporter and glucose transporter 1 , respectively [21, 58]. Senkel et al. identified 25 target genes of HNF $1 \beta$ in a human embryonic kidney cell line, which includes dipeptidyl peptidase 4 (DPP4), which is known to play a major role in glucose metabolism [59]. Gregori et al. found that the expression of aldolase B, an enzyme that is

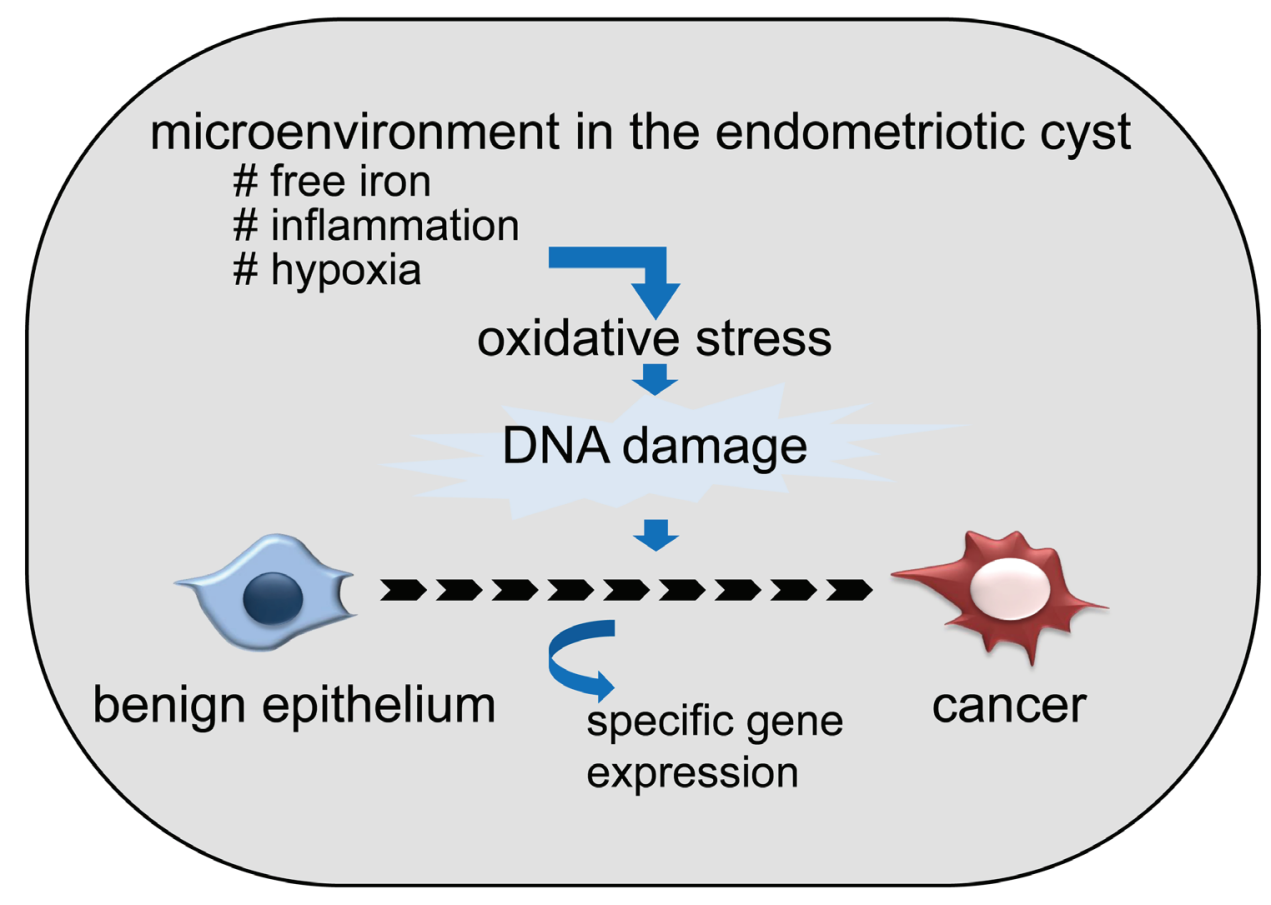

Figure 1: Possible contribution of unique microenvironment in endometriotic cyst to the frequent development of ovarian cancer. Microenvironment, especially high concentration of free iron, which derived from old blood accumulated in the cyst, causes oxidative stress (ROS), and causes DNA damage. Accumulation of DNA damage over the years eventually leads to the cancer development. 
involved in two opposite metabolic pathways, glycolysis and gluconeogenesis, is controlled by the two HNF1 binding sites in the enhancer [60].

Actually, we noticed a functional link between HNF $1 \beta$ and cell metabolism in our own experiments [21]. We knocked down the expression of HNF1 $\beta$ by shRNA in RMG2 human OCCC cells, which originally has high expression of HNF1 $\beta$. Then, we found that the growth of HNF1 $\beta$-high original RMG2 was slower than HNF1 $\beta$ knockdown RMG2. Nevertheless, we noticed that the color of the media in HNF1 $\beta$-high original RMG2 tended to be yellow compared to the HNF1 $1 \beta$ knockdown RMG2, leading to the finding that lactic acid accumulates more in the former. These results suggest that HNF1 $\beta$-high RMG2 exhibited higher glucose metabolism, but it was not the consequence of rapid cell proliferation [21]. We further elucidated this seemingly curious phenomenon in detail, and we found that glucose uptake, as well as glycolysis, is significantly higher in HNF1 $\beta$-high RMG2. These metabolic changes are consistent with "the Warburg effect". However, the biological influence, perhaps an advantageous influence, of such metabolic alteration for OCCC cells remained unclear. It was not likely that higher glucose uptake directly contributed to cell proliferation, as stated above.

To explore the intracellular metabolic change triggered by HNF $1 \beta$ expression, in the study in this issue of journal, we performed a comprehensive metabolite analysis (the metabolome assay) between HNF1 $\beta$-high RMG2 and HNF1 $\beta$ knockdown RMG2 cells [61]. As expected, repression of HNF $1 \beta$ expression caused drastic intracellular metabolic alteration. The most prominent alteration is the increase in glycolysis and, on the other hand, the decrease in oxidative phosphorylation. Because this shift is the main component of the Warburg effect, we can say that HNF $1 \beta$ enhances the Warburg effect in OCCC cells. One question remains: why (for what purpose) do OCCC cells employ such metabolic activity? To answer this question, I will next discuss the biological aspect of the Warburg effect.

\section{BIOLOGICAL ASPECT OF THE WARBURG EFFECT AND THE ROLE OF HNF1B}

Since Warburg first reported unique cancer metabolism, a number of researchers have tried to explain how it contributes to cancer biology. Warburg himself already noticed that this metabolic reprograming does not simply enable cancer cells to live under hypoxic conditions because the Warburg effect is also observed in the environment with abundant oxygen. He speculated that mitochondrial dysfunction in cancer cells hampers oxidative phosphorylation and forced them to switch to glycolysis [62]. However, recent studies have revealed that many cancers do not necessarily have mitochondrial defects [23], or mitochondrial dysfunction does not always linked to Warburg effect [63]. The apparent advantage of energy production by glycolysis is that, if cancer cells have a sufficient glucose supply available, they can produce energy more quickly by glycolysis than by oxidative phosphorylation even under normoxic conditions. Moreover, glycolysis can support cell proliferation in other processes, supplying substances such as nucleotides, amino acids and lipids for biosynthesis. In term of material supply for cell growth, glycolysis is more efficient than oxidative phosphorylation [64-66].

In addition to supporting cell proliferation, the metabolism shift from oxidative phosphorylation to aerobic glycolysis confers another important advantage for cancer cells, namely, cell survival $[66,67]$. Suppression of oxidative phosphorylation compromises intrinsic apoptosis through inhibition of proapoptotic proteins, Bax and Bak, and through reduction of ROS production in mitochondria. From this viewpoint, we analyzed the whole metabolic process in HNF1 $\beta$-high and low RMG2 cells, and obtained several notable findings [61]. First, we could not detect any findings that HNF1 $\beta$-induced metabolic change contributes to cell proliferation. Second, neither energy nor biomass production seemed augmented in HNF1 $\beta$-high RMG2. Actually, these were in accordance with the fact that HNF1 $\beta$ knockdown RMG2 grow more rapidly than HNF1 $\beta$-high RMG2, as mentioned earlier. Clinically, OCCC is known as a relatively slowgrowing tumor, which may explain why it does not receive growth benefit from the Warburg effect. Third, survival of HNF1 $\beta$-high RMG2 was significantly better compared with HNF1 $\beta$ _knockdown RMG2 especially under hypoxic conditions. Furthermore, these cells were more resistant to CDDP treatment in hypoxic conditions compared with HNF1 $\beta$ knockdown RMG2. Most importantly, survival benefit of HNF1 $\beta$-high RMG2 was significantly impaired in low glucose conditions, suggesting that cell survival of HNF1 $\beta$-high RMG2 is highly dependent of glucose uptake and consumption.

We then measured intracellular ROS activity in these cells, which indicated that HNF1 $\beta$-high RMG2 had lower levels of intracellular ROS. When these cells were exposed to known extracellular oxidative stressors such as ferric nitrilotriacetate (FeNTA) or $\mathrm{H}_{2} \mathrm{O}_{2}$, $\mathrm{HNF} 1 \beta$-high RMG2 had lower ROS activity levels compared with their HNF1 $\beta$ knockdown counterparts [61].

These data collectively suggest that, HNF $1 \beta$ reduces oxidative phosphorylation, which is the primary source of intracellular ROS, by increasing the oxygen-independent glycolysis, and confers ROS resistance in OCCC cells. Therefore, in this particular case, the Warburg effect primarily contributes cell survival, rather than cell proliferation. Thus, the Warburg effect, which represents frequently observed metabolic alterations in cancers, may comprise of different mechanisms with different biological consequence according to the cancer types and their requirements. 


\section{HNF1B CONFERS ROS RESISTANCE BY MULTIPLE MECHANISMS}

In addition to the findings above, our study revealed that HNF1 $\beta$ also contributes ROS reduction with mechanisms other than the Warburg effect [61]. HNF1 $\beta$-high RMG2 had significantly higher activity of intracellular GSH, a major regulator of intracellular ROS. Furthermore, rBAT, a cystine transporter, was expressed at significantly higher levels in these cells. Knockdown of rBAT by sh-RNA resulted in decreased levels of intracellular GSH and increased ROS activity, suggesting that rBAT plays a major role in HNF1 $\beta$-triggered ROS resistance. These results strongly suggest that one of the primary roles of HNF $1 \beta$ is to avoid cellular oxidative stress and to enable cells to survive under stressful environments.

There are no reports indicating that HNF1 $\beta$ contributes to ROS resistance. However, Qadri et al. reported that HNF1 and HNF4 mediate hepatic multidrug resistance protein 2 up-regulation during hepatitis $\mathrm{C}$ virus gene expression, which may contribute to the cellular detoxification against ROS produced during HCV infection [68]. Wobser et al. reported that suppression of HNF-1 alpha results in mitochondrial dysfunction, cell apoptosis, and increased sensitivity to ceramide [69]. These data suggest that the HNF signal, as a whole, confers ROS resistance and anti-apoptotic effect.

\section{WHY DOES OCCC SPECIFICALLY UNDERTAKE UNIQUE METABOLIC ACTIVITY AMONG OVARIAN CANCERS?}

The induction of HNF1 $\beta$ is reasonable in terms of the microenvironment with which these cells have to cope. As shown above, endometrioid epithelial cells are continuously exposed to severe oxidative stress caused by the contents of the cyst $[10,19]$. Therefore, the primary requirement for survival of endometrial epithelial cells is the anti-stress capacity rather than proliferative potential. It is likely that HNF $1 \beta$ is induced for this purpose and its expression is maintained throughout malignant progression (Figure 2). HNF1 $\beta$, as a transcription factor, induces multiple genes which participate in the Warburg effect, but other mechanisms also serve as tools to escape from intracellular stress.

This is particularly important from a clinical point of view because the stress-resistant characteristic of OCCC may lead to the chemo-resistance as we report in this issue. Tamada et al. reported similar findings on CD44, a cell adhesion molecule, which interacted with pyruvate kinase M2 and enhances glycolysis [70]. Ablation of CD44 resulted in the reduction of GSH, the increase in intracellular ROS, and enhanced the effect of chemotherapeutic drugs.

\section{stressful environment in the endometriotic cyst}
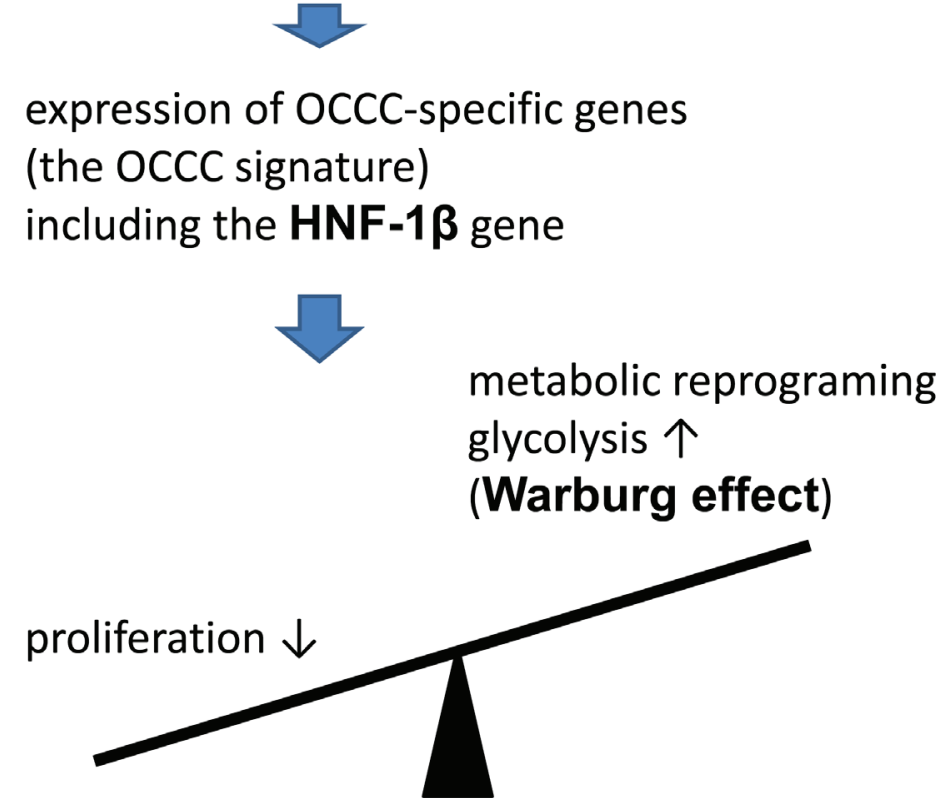

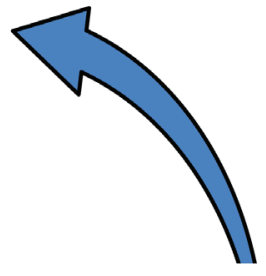

anti-stress mechanism (ROS reduction, anti-apoptosis)

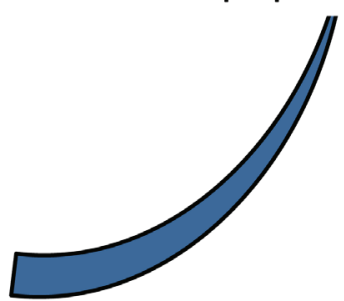

Figure 2: Mechanism that OCCC cope with environmental oxidative stress. Oxidative stress induces a set of OCCC-specific genes, which we designated as the OCCC signature. HNF-1b, one of the most important transcriptional factors in the OCCC signature genes, suppresses cell growth on the one hand, and enhances survival mechanism by the metabolic reprogramming on the other hand. 


\section{HNF1B AND SUBSEQUENT METABOLIC ALTERATIONS AS POSSIBLE THERAPEUTIC TARGETS FOR OCCC}

Currently, most of the cancer chemotherapies target cell proliferation. However, with growing evidence accumulating that indicates the importance of cancerspecific metabolism, attempts to use modification of cancer metabolism as therapeutic target are also being focused [71, 72]. PI3K pathway, one of the most commonly activated signaling pathways in cancers including OCCC, has recently been implicated in glycolytic activity [7375]. Activated Akt signal was shown to stimulates aerobic glycolysis and maintain cell survival and resistance to apoptosis $[31,76]$. It is assumed that oncogenes/tumor suppressor genes are more or less linked to the metabolic activity of cancer cells [30-34, 70, 71, 77]. Therefore, molecular target therapy against these signals might modulate intracellular metabolism toward anticancer effect $[30,78,79]$.

More specific strategies to target metabolism itself are also being developed. PKM2, an isoform of PK, which catalyzes the conversion of phosphoenolpyruvate to pyruvate, is known to play a key role in glucose metabolism, and several small-molecule PKM2 activators are being developed. Likewise, inhibitors of phosphoglycerate mutase 1 (PGAM1) and mutant isocitrate dehydrogenase (IDH), both catalases involved in glycolysis in cancer cells, are considered to be promising candidates as cancer drugs [80].

Because it has been reported that the Warburg effect as well as other metabolic alterations affect mitochondrial function, ROS production, and eventual apoptosis, each step involved in the oxidative phosphorylation is also a candidate target. It has been shown that suppression of glycolysis and shift to mitochondrial oxidation leads to cancer cell death [81].

Our study on the metabolic alterations caused by HNF $1 \beta$ in OCCC evokes some hints to disease management, as each step of clarified alterations could be candidate targets for treatment (Figure 3). First, we demonstrated that oxidative stress in the endometriotic cyst has causative relationship to OCCC [19]. Improvement of such microenvironment by surgical treatment may reduce the risk of cancer development. Second, we showed that HNF $1 \beta$ augments cell survival by enhancing ROS resistance in OCCC. HNF1 $1 \beta$ inhibition with some type of inhibitor, such as the microRNA mir-802 [82], may

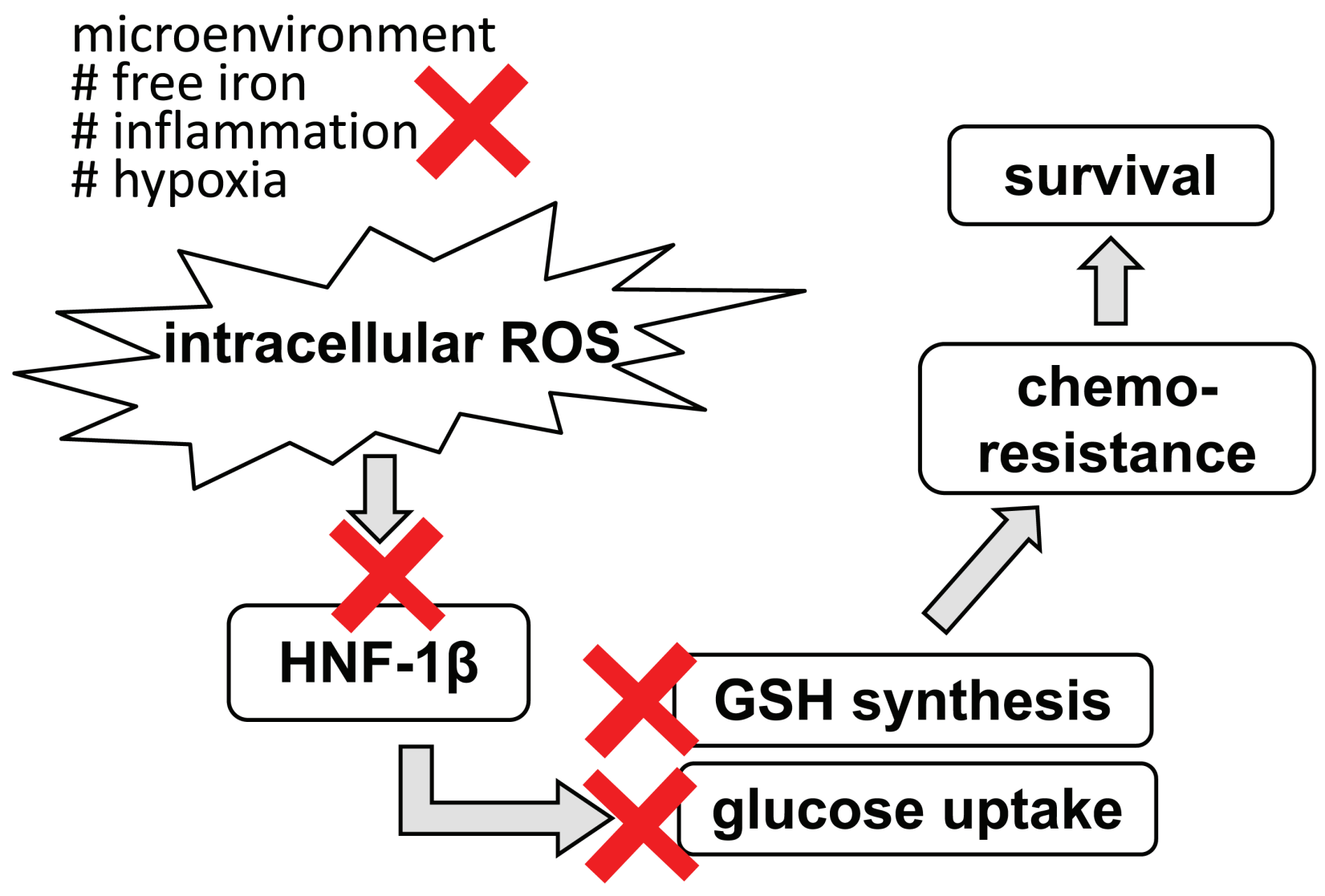

Figure 3: Potential therapeutic target for OCCC in terms of stress response. Primarily, improvement of stressful environment by the surgical intervention may lead to inhibition of cancer occurrence. In addition, interventions into each step of HNF-1 $\beta$-related survival mechanism may provide more specific targeted therapy. 
have a therapeutic effect by abrogating ROS resistance. Third, our data indicated that HNF1 $\beta$-induced cell survival is dependent on the glucose supply. HNF1 $\beta$-high RMG2 cells were more vulnerable to glucose deprivation. Several reports suggested that glucose deprivation is critical in cancers displaying the Warburg effect [72, 83, 84]. Therefore, glucose metabolism may be a therapeutic target in OCCC with high HNF1 $\beta$ expression. In ovarian cancer, metformin, an anti-diabetic drug, was shown to inhibit cancer growth and increase paclitaxel sensitivity in mouse model [85]. More specific reagents were also indicated to have anti-tumor effect by altering glycolytic activity [86-88] in vitro and in animal experiments. Tamada et al. showed that modulation of glucose metabolism by CD44 contributes to the antioxidant status and drug resistance in cancer cells [70]. Human trial, especially from large studies, are not available yet, and to be evaluated in future. Finally, inhibition of GSH synthesis using reagents such as buthionine sulfoximine $[89,90]$, or inhibition of GSH synthesis by targeting the cystine transporter rBAT, may enhance the effect of conventional chemotherapy.

\section{CONCLUSIONS}

Our studies along with others have started to explore the importance of cancer-specific metabolism in pursuing the cancer biology and also therapeutic application. Our serial studies suggest the possibility that cells maneuver their own metabolism to survive under stressful environments, and cancers that arise in such stressful conditions exhibit metabolic activity fine-tuned to resist intracellular stress, which may, in turn, leads to the drug resistance.

Cancer specific metabolic activity could be a promising target as an individualized treatment in various cancers, and for this purpose, clarifying the features of metabolic activity in each cancer is needed.

\section{Abbreviations}

HNF1 $\beta$, hepatocyte nuclear factor $1 \beta$; OCCC, ovarian clear cell carcinoma; ROS, reactive oxygen species

\section{REFERENCES}

1. Sugiyama T, Kamura T, Kigawa J, Terakawa N, Kikuchi Y, Kita T, Suzuki M, Sato I, Taguchi K. Clinical characteristics of clear cell carcinoma of the ovary: a distinct histologic type with poor prognosis and resistance to platinum-based chemotherapy. Cancer. 2000 Jun 1;88:2584-9.

2. Crotzer DR, Sun CC, Coleman RL, Wolf JK, Levenback $\mathrm{CF}$, Gershenson DM. Lack of effective systemic therapy for recurrent clear cell carcinoma of the ovary. Gynecol Oncol. 2007 May;105:404-8.
3. Itamochi H, Kigawa J, Sultana H, Iba T, Akeshima R, Kamazawa S, Kanamori Y, Terakawa N. Sensitivity to anticancer agents and resistance mechanisms in clear cell carcinoma of the ovary. Jpn J Cancer Res. 2002 Jun;93:7238.

4. Eltabbakh GH, Mount SL, Beatty B, Simmons-Arnold L, Cooper K. Clinical and molecular differences between clear cell and papillary serous ovarian carcinoma. J Surg Oncol. 2006 Apr 1;93:379-86.

5. Lim MC, Park SH, Park SY. Ovarian clear cell carcinoma: high risk of venous thromboembolism. Gynecol Oncol. 2010 Sep;118:317

6. Abu Saadeh F, Norris L, O'Toole S, Gleeson N. Venous thromboembolism in ovarian cancer: incidence, risk factors and impact on survival. Eur J Obstet Gynecol Reprod Biol. 2013 Sep;170:214-8.

7. Duska LR, Garrett L, Henretta M, Ferriss JS, Lee L, Horowitz N. When 'never-events' occur despite adherence to clinical guidelines: the case of venous thromboembolism in clear cell cancer of the ovary compared with other epithelial histologic subtypes.Gynecol Oncol. 2010 Mar;116:374-7.

8. Mandai M, Yamaguchi K, Matsumura N, Baba T, Konishi I. Ovarian cancer in endometriosis: molecular biology, pathology, and clinical management. Int J Clin Oncol. 2009 Oct;14:383-91.

9. Kobayashi H, Sumimoto K, Kitanaka T, Yamada Y, Sado T, Sakata M, Yoshida S, Kawaguchi R, Kanayama S, Shigetomi H, Haruta S, Tsuji Y, Ueda S, Terao T. Ovarian endometrioma-risks factors of ovarian cancer development. Eur J Obstet Gynecol Reprod Biol. 2008 Jun;138:187-93.

10. Mandai M, Matsumura N, Baba T, Yamaguchi K, Hamanishi J, Konishi I. Ovarian clear cell carcinoma as a stress-responsive cancer: influence of the microenvironment on the carcinogenesis and cancer phenotype. Cancer Lett. 2011 Nov 28;310:129-33.

11. Jones S, Wang TL, Shih IeM, Mao TL, Nakayama K, Roden R, Glas R, Slamon D, Diaz LA Jr, Vogelstein B, Kinzler KW, Velculescu VE, Papadopoulos N. Frequent mutations of chromatin remodeling gene ARID1A in ovarian clear cell carcinoma. Science. 2010 Oct 8;330:228-31.

12. Wiegand KC, Shah SP, Al-Agha OM, Zhao Y, Tse K, Zeng T, Senz J, McConechy MK, Anglesio MS, Kalloger SE, Yang W, Heravi-Moussavi A, Giuliany R, Chow C, et al. ARID1A mutations in endometriosis-associated ovarian carcinomas. N Engl J Med. 2010 Oct 14;363:1532-43.

13. Katagiri A, Nakayama K, Rahman MT, Rahman M, Katagiri H, Nakayama N, Ishikawa M, Ishibashi T, Iida K, Kobayashi H, Otsuki Y, Nakayama S, Miyazaki K. Loss of ARID1A expression is related to shorter progressionfree survival and chemoresistance in ovarian clear cell carcinoma. Mod Pathol. 2012 Feb;25:282-8.

14. Kuo KT, Mao TL, Jones S, Veras E, Ayhan A, Wang TL, 
Glas R, Slamon D, Velculescu VE, Kuman RJ, Shih IeM. Frequent activating mutations of PIK3CA in ovarian clear cell carcinoma. Am J Pathol. 2009 May;174:1597-601.

15. Yamamoto S, Tsuda H, Takano M, Iwaya K, Tamai S, Matsubara O. PIK3CA mutation is an early event in the development of endometriosis-associated ovarian clear cell adenocarcinoma. J Pathol. 2011 Oct;225:189-94.

16. Tsuchiya A, Sakamoto M, Yasuda J, Chuma M, Ohta T, Ohki M, Yasugi T, Taketani Y, Hirohashi S. Expression profiling in ovarian clear cell carcinoma: identification of hepatocyte nuclear factor-1 beta as a molecular marker and a possible molecular target for therapy of ovarian clear cell carcinoma. Am J Pathol. 2003 Dec;163:2503-12.

17. Kato N, Sasou S, Motoyama T. Expression of hepatocyte nuclear factor-1beta (HNF-1beta) in clear cell tumors and endometriosis of the ovary. Mod Pathol. 2006 Jan;19:83-9.

18. Matsumura N, Mandai M, Okamoto T, Yamaguchi K, Yamamura S, Oura T, Baba T, Hamanishi J, Kang HS, Matsui S, Mori S, Murphy SK, Konishi I. Sorafenib efficacy in ovarian clear cell carcinoma revealed by transcriptome profiling. Cancer Sci. 2010 Dec;101:2658-63.

19. Yamaguchi K, Mandai M, Toyokuni S, Hamanishi J, Higuchi T, Takakura K, Fujii S. Contents of endometriotic cysts, especially the high concentration of free iron, are a possible cause of carcinogenesis in the cysts through the iron-induced persistent oxidative stress. Clin Cancer Res. 2008 Jan 1;14:32-40.

20. Yamaguchi K, Mandai M, Oura T, Matsumura N, Hamanishi J, Baba T, Matsui S, Murphy SK, Konishi I. Identification of an ovarian clear cell carcinoma gene signature that reflects inherent disease biology and the carcinogenic processes. Oncogene. 2010 Mar 25;29:174152.

21. Okamoto T, Mandai M, Matsumura N, Yamaguchi K, Kondoh H, Amano Y, Baba T, Hamanishi J, Abiko K, Kosaka K, Murphy SK, Mori S, Konishi I. Hepatocyte nuclear factor-1 $\beta$ (HNF-1 $\beta$ ) promotes glucose uptake and glycolytic activity in ovarian clear cell carcinoma. Mol Carcinog. 2015 Jan;54:35-49.

22. Racker E. Bioenergetics and the problem of tumor growth. Am Sci. 1972 Jan-Feb;60:56-63.

23. Koppenol WH, Bounds PL, Dang CV. Otto Warburg's contributions to current concepts of cancer metabolism. Nat Rev Cancer. 2011 May;11:325-37.

24. Kim JW, Dang CV. Cancer's molecular sweet tooth and the Warburg effect. Cancer Res. 2006 Sep 15;66:8927-30.

25. Samudio I, Fiegl M, Andreeff M. Mitochondrial uncoupling and the Warburg effect: molecular basis for the reprogramming of cancer cell metabolism. Cancer Res. 2009 Mar 15;69:2163-6.

26. Dang CV. Links between metabolism and cancer. Genes Dev. 2012 May 1;26:877-90.

27. Chung HH, Kwon HW, Kang KW, Park NH, Song YS, Chung JK, Kang SB, Kim JW. Prognostic value of preoperative metabolic tumor volume and total lesion glycolysis in patients with epithelial ovarian cancer. Ann Surg Oncol. 2012 Jun;19:1966-72.

28. Konishi H, Takehara K, Kojima A, Okame S, Yamamoto Y, Shiroyama Y, Yokoyama T, Nogawa T, Sugawara Y. Maximum standardized uptake value of fluorodeoxyglucose positron emission tomography/computed tomography is a prognostic factor in ovarian clear cell adenocarcinoma. Int J Gynecol Cancer. 2014 Sep;24:1190-4.

29. Tanizaki Y, Kobayashi A, Shiro M, Ota N, Takano R, Mabuchi Y, Yagi S, Minami S, Terada M, Ino K. Diagnostic value of preoperative SUVmax on FDG-PET/CT for the detection of ovarian cancer. Int J Gynecol Cancer. 2014 Mar;24:454-60.

30. Blum R, Jacob-Hirsch J, Amariglio N, Rechavi G, Kloog Y. Ras inhibition in glioblastoma down-regulates hypoxiainducible factor-1alpha, causing glycolysis shutdown and cell death. Cancer Res. 2005 Feb 1;65:999-1006.

31. Elstrom RL, Bauer DE, Buzzai M, Karnauskas R, Harris MH, Plas DR, Zhuang H, Cinalli RM, Alavi A, Rudin CM, Thompson CB. Akt stimulates aerobic glycolysis in cancer cells. Cancer Res. 2004 Jun 1;64:3892-9.

32. Osthus RC, Shim H, Kim S, Li Q, Reddy R, Mukherjee $\mathrm{M}, \mathrm{Xu}$ Y, Wonsey D, Lee LA, Dang CV. Deregulation of glucose transporter 1 and glycolytic gene expression by c-Myc. J Biol Chem. 2000 Jul 21;275:21797-800.

33. Gordan JD, Thompson CB, Simon MC. HIF and c-Myc: sibling rivals for control of cancer cell metabolism and proliferation. Cancer Cell. 2007 Aug;12:108-13

34. Jiang P, Du W, Wang X, Mancuso A, Gao X, Wu M, Yang $\mathrm{X}$. p53 regulates biosynthesis through direct inactivation of glucose-6-phosphate dehydrogenase. Nat Cell Biol. 2011 Mar; 13:310-6.

35. Kew MC. Hepatic iron overload and hepatocellular carcinoma. Liver Cancer. 2014 Mar;3:31-40.

36. Kamp DW. Asbestos-induced lung diseases: an update. Transl Res. 2009 Apr;153:143-52.

37. Bystrom LM, Rivella S. Cancer cells with irons in the fire. Free Radic Biol Med. 2015 Feb;79:337-42.

38. Yamaguchi K, Huang Z, Matsumura N, Mandai M, Okamoto T, Baba T, Konishi I, Berchuck A, Murphy SK. Epigenetic determinants of ovarian clear cell carcinoma biology. Int J Cancer. 2014 Aug 1;135:585-97.

39. Yamaguchi K, Matsumura N, Mandai M, Baba T, Konishi I, Murphy SK. Epigenetic and genetic dispositions of ovarian carcinomas. Oncoscience. 2014 Sep 22;1:574-9.

40. Kato N, Motoyama T. Hepatocyte nuclear factorlbeta(HNF-1beta) in human urogenital organs: its expression and role in embryogenesis and tumorigenesis. Histol Histopathol. 2009 Nov;24:1479-86.

41. Lokmane L, Haumaitre C, Garcia-Villalba P, Anselme I, Schneider-Maunoury S, Cereghini S. Crucial role of vHNF1 in vertebrate hepatic specification. Development. 2008 Aug;135:2777-86. 
42. Haumaitre C, Barbacci E, Jenny M, Ott MO, Gradwohl $\mathrm{G}$, Cereghini S. Lack of TCF2/vHNF1 in mice leads to pancreas agenesis. Proc Natl Acad Sci U S A. 2005 Feb 1;102:1490-5.

43. Maestro MA, Cardalda C, Boj SF, Luco RF, Servitja JM, Ferrer J. Distinct roles of HNF1beta, HNF1alpha, and HNF4alpha in regulating pancreas development, beta-cell function and growth. Endocr Dev. 2007;12:33-45.

44. Naylor RW, Przepiorski A, Ren Q, Yu J, Davidson AJ. HNF1 $\beta$ is essential for nephron segmentation during nephrogenesis. J Am Soc Nephrol. 2013 Jan;24:77-87.

45. Horikawa Y, Iwasaki N, Hara M, Furuta H, Hinokio Y, Cockburn BN, Lindner T, Yamagata K, Ogata M, Tomonaga O, Kuroki H, Kasahara T, Iwamoto Y, Bell GI. Mutation in hepatocyte nuclear factor-1 beta gene (TCF2) associated with MODY. Nat Genet. 1997 Dec;17:384-5.

46. Fajans SS, Bell GI, Polonsky KS. Molecular mechanisms and clinical pathophysiology of maturity-onset diabetes of the young. N Engl J Med. 2001 Sep 27;345:971-80.

47. Bingham C, Hattersley AT. Renal cysts and diabetes syndrome resulting from mutations in hepatocyte nuclear factor-1beta. Nephrol Dial Transplant. 2004 Nov;19:27038 .

48. Raaijmakers A, Corveleyn A, Devriendt K, van Tienoven TP, Allegaert K, Van Dyck M, van den Heuvel L, Kuypers D, Claes K, Mekahli D, Levtchenko E. Criteria for HNF1B analysis in patients with congenital abnormalities of kidney and urinary tract. Nephrol Dial Transplant. 2014 Dec 13. pii: gfu370. [Epub ahead of print]

49. Ogata K, Shimamura Y, Hamada K, Hisa M, Bun M, Okada $\mathrm{N}$, Inoue K, Taniguchi $\mathrm{Y}$, Ishihara $\mathrm{M}$, Kagawa $\mathrm{T}$, Horino T, Fujimoto S, Terada Y. Upregulation of HNF-1 $\beta$ during experimental acute kidney injury plays a crucial role in renal tubule regeneration. Am J Physiol Renal Physiol. 2012 Sep;303:F689-99.

50. Faguer S, Mayeur N, Casemayou A, Pageaud AL, Courtellemont C, Cartery C, Fournie GJ, Schanstra JP, Tack I, Bascands JL, Chauveau D. Hnf-1 $\beta$ transcription factor is an early hif- $1 \alpha$-independent marker of epithelial hypoxia and controls renal repair. PLoS One. 2013 May 21;8:e63585.

51. Grisanzio C, Werner L, Takeda D, Awoyemi BC, Pomerantz MM, Yamada H, Sooriakumaran P, Robinson BD, Leung R, Schinzel AC, Mills I, Ross-Adams H, Neal DE, et al. Genetic and functional analyses implicate the NUDT11, HNF1B, and SLC22A3 genes in prostate cancer pathogenesis. Proc Natl Acad Sci U S A. 2012 Jul 10;109:11252-7.

52. Debiais-Delpech C, Godet J, Pedretti N, Bernard FX, Irani J, Cathelineau X, Cussenot O, Fromont G. Expression patterns of candidate susceptibility genes HNF1 $\beta$ and CtBP2 in prostate cancer: association with tumor progression. Urol Oncol. 2014 May;32:426-32.

53. Shim JH, Lee HC, Han S, Kang HJ, Yu E, Lee SG.
Hepatocyte nuclear factor $1 \beta$ is a novel prognostic marker independent of the Milan criteria in transplantable hepatocellular carcinoma: a retrospective analysis based on tissue microarrays. Liver Transpl. 2013 Mar;19:336-45.

54. Ma Z, Gong Y, Patel V, Karner CM, Fischer E, Hiesberger T, Carroll TJ, Pontoglio M, Igarashi P. Mutations of HNF-1beta inhibit epithelial morphogenesis through dysregulation of SOCS-3. Proc Natl Acad Sci U S A. 2007 Dec 18;104:20386-91.

55. D'Angelo A, Bluteau O, Garcia-Gonzalez MA, Gresh L, Doyen A, Garbay S, Robine S, Pontoglio M. Hepatocyte nuclear factor 1alpha and beta control terminal differentiation and cell fate commitment in the gut epithelium. Development. 2010 May;137:1573-82.

56. Kikuchi R, Kusuhara H, Hattori N, Kim I, Shiota K, Gonzalez FJ, Sugiyama Y. Regulation of tissue-specific expression of the human and mouse urate transporter 1 gene by hepatocyte nuclear factor 1 alpha/beta and DNA methylation. Mol Pharmacol. 2007 Dec;72:1619-25.

57. Jin L, Kikuchi R, Saji T, Kusuhara H, Sugiyama Y. Regulation of tissue-specific expression of renal organic anion transporters by hepatocyte nuclear factor $1 \alpha / \beta$ and DNA methylation. J Pharmacol Exp Ther. 2012 Mar;340:648-55.

58. Balakrishnan A, Stearns AT, Rhoads DB, Ashley SW, Tavakkolizadeh A. Defining the transcriptional regulation of the intestinal sodium-glucose cotransporter using RNA-interference mediated gene silencing. Surgery. 2008 Aug;144:168-73.

59. Senkel S, Lucas B, Klein-Hitpass L, Ryffel GU. Identification of target genes of the transcription factor HNF1beta and HNF1alpha in a human embryonic kidney cell line. Biochim Biophys Acta. 2005 Dec 20;1731:179-90.

60. Gregori C, Porteu A, Mitchell C, Kahn A, Pichard AL. In vivo functional characterization of the aldolase $\mathrm{B}$ gene enhancer. J Biol Chem. 2002 Aug 9;277:28618-23.

61. Amano Y, Mandai M, Yamaguchi K, Matsumura N, KharmaB, Baba T, Abiko K, Hamanishi J, Yoshioka Y, Konishi I. Metabolic alterations caused by HNF1 $\beta$ expression in ovarian clear cell carcinoma contribute to cell survival. Oncotarget. 2015 in press

62. Warburg O. On the origin of cancer cells. Science. 1956 Feb 24;123:309-14.

63. Boland ML, Chourasia AH, Macleod KF. Mitochondrial dysfunction in cancer. Front Oncol. 2013 Dec 2;3:292.

64. Hsu PP, Sabatini DM. Cancer cell metabolism: Warburg and beyond. Cell. 2008 Sep 5;134:703-7.

65. Vander Heiden MG, Cantley LC, Thompson CB. Qadri I, Iwahashi M, Kullak-Ublick GA, Simon FR. Understanding the Warburg effect: the metabolic requirements of cell proliferation. Science. 2009 May 22;324:1029-33.

66. Chen X, Qian Y, Wu S. The Warburg effect: evolving interpretations of an established concept. Free Radic Biol Med. 2015 Feb;79:253-63. 
67. Stine ZE1, Dang CV. Stress eating and tuning out: cancer cells re-wire metabolism to counter stress.Crit Rev Biochem Mol Biol. 2013 Nov-Dec;48:609-19.

68. Qadri I, Iwahashi M, Kullak-Ublick GA, Simon FR. Hepatocyte nuclear factor (HNF) 1 and HNF4 mediate hepatic multidrug resistance protein 2 up-regulation during hepatitis C virus gene expression. Mol Pharmacol. 2006 Aug;70:627-36.

69. Wobser H, Düssmann H, Kögel D, Wang H, Reimertz C, Wollheim CB, Byrne MM, Prehn JH. Dominant-negative suppression of HNF-1 alpha results in mitochondrial dysfunction, INS-1 cell apoptosis, and increased sensitivity to ceramide-, but not to high glucose-induced cell death. J Biol Chem. 2002 Feb 22;277:6413-21.

70. Tamada M, Nagano O, Tateyama S, Ohmura M, Yae T, Ishimoto T, Sugihara E, Onishi N, Yamamoto T, Yanagawa H, Suematsu M, Saya H. Modulation of glucose metabolism by CD44 contributes to antioxidant status and drug resistance in cancer cells. Cancer Res. 2012 Mar $15 ; 72: 1438-48$.

71. Kroemer G, Pouyssegur J. Tumor cell metabolism: cancer's Achilles' heel. Cancer Cell. 2008 Jun;13:472-82.

72. Galluzzi L, Kepp O, Vander Heiden MG, Kroemer G. Metabolic targets for cancer therapy. Nat Rev Drug Discov. 2013 Nov;12:829-46.

73. Makinoshima H, Takita M, Saruwatari K, Umemura S, Obata Y, Ishii G, Matsumoto S, Sugiyama E, Ochiai A, Abe R, Goto K, Esumi H, Tsuchihara K. Signaling through the Phosphatidylinositol 3-Kinase (PI3K)/ Mammalian Target of Rapamycin (mTOR) Axis is Responsible for Aerobic Glycolysis mediated by Glucose Transporter in Epidermal Growth Factor Receptor (EGFR)-mutated Lung Adenocarcinoma. J Biol Chem. 2015 May 28. pii: jbc. M115.660498. [Epub ahead of print]

74. Courtnay R, Ngo DC, Malik N, Ververis K, Tortorella SM, Karagiannis TC. Cancer metabolism and the Warburg effect: the role of HIF-1 and PI3K. Mol Biol Rep. 2015 Apr;42:841-51.

75. Sun Q, Chen X, Ma J, Peng H, Wang F, Zha X, Wang Y, Jing Y, Yang H, Chen R, Chang L, Zhang Y, Goto J, Onda H, Chen T, Wang MR, Lu Y, You H, Kwiatkowski D, Zhang H. Mammalian target of rapamycin up-regulation of pyruvate kinase isoenzyme type M2 is critical for aerobic glycolysis and tumor growth. Proc Natl Acad Sci U S A. 2011 Mar 8;108:4129-34.

76. Coloff JL, Macintyre AN, Nichols AG, Liu T, Gallo CA, Plas DR, Rathmell JC. Akt-dependent glucose metabolism promotes Mcl-1 synthesis to maintain cell survival and resistance to Bcl-2 inhibition. Cancer Res. 2011 Aug 1;71:5204-13.

77. Verschoor ML, Verschoor CP, Singh G. Ets-1 global gene expression profile reveals associations with metabolism and oxidative stress in ovarian and breast cancers. Cancer Metab. 2013 Jul 25;1:17.
78. Xu RH, Pelicano H, Zhou Y, Carew JS, Feng L, Bhalla $\mathrm{KN}$, Keating MJ, Huang P. Inhibition of glycolysis in cancer cells: a novel strategy to overcome drug resistance associated with mitochondrial respiratory defect and hypoxia. Cancer Res. 2005 Jan 15;65:613-21.

79. Liu Y, Cao Y, Zhang W, Bergmeier S, Qian Y, Akbar H, Colvin R, Ding J, Tong L, Wu S, Hines J, Chen X. A smallmolecule inhibitor of glucose transporter 1 downregulates glycolysis, induces cell-cycle arrest, and inhibits cancer cell growth in vitro and in vivo. Mol Cancer Ther. 2012 Aug;11:1672-82.

80. Elf SE, Chen J. Targeting glucose metabolism in patients with cancer. Cancer. 2014 Mar 15;120:774-80.

81. Ngo H, Tortorella SM, Ververis K, Karagiannis TC. The Warburg effect: molecular aspects and therapeutic possibilities. Mol Biol Rep. 2014 Sep 25. [Epub ahead of print]

82. Kornfeld JW, Baitzel C, Könner AC, Nicholls HT, Vogt MC, Herrmanns K, Scheja L, Haumaitre C, Wolf AM, Knippschild U, Seibler J, Cereghini S, Heeren J, Stoffel M, Brüning JC. Obesity-induced overexpression of miR-802 impairs glucose metabolism through silencing of Hnflb. Nature. 2013 Feb 7;494:111-5.

83. Zhao Y, Butler EB, Tan M. Targeting cellular metabolism to improve cancer therapeutics. Cell Death Dis. 2013 Mar 7;4:e532.

84. Vaughan RA, Garcia-Smith R, Dorsey J, Griffith JK, Bisoffi M, Trujillo KA. Tumor necrosis factor alpha induces Warburg-like metabolism and is reversed by antiinflammatory curcumin in breast epithelial cells. Int J Cancer. 2013 Nov 15;133:2504-10.

85. Lengyel E, Litchfield LM, Mitra AK, Nieman KM, Mukherjee A, Zhang Y, Johnson A, Bradaric M, Lee W, Romero IL. Metformin inhibits ovarian cancer growth and increases sensitivity to paclitaxel in mouse models. Am J Obstet Gynecol. 2015 Apr;212:479.e1-479.e10.

86. Qiu H, Jackson AL, Kilgore JE, Zhong Y, Chan LL, Gehrig PA, Zhou C, Bae-Jump VL. JQ1 suppresses tumor growth through downregulating LDHA in ovarian cancer. Oncotarget. 2015 Mar 30;6:6915-30.

87. Reutter M, Emons G, Gründker C. Starving tumors: inhibition of glycolysis reduces viability of human endometrial and ovarian cancer cells and enhances antitumor efficacy of GnRH receptor-targeted therapies. Int J Gynecol Cancer. 2013 Jan;23:34-40.

88. Alvero AB, Montagna MK, Sumi NJ, Joo WD, Graham E, Mor G. Multiple blocks in the engagement of oxidative phosphorylation in putative ovarian cancer stem cells: implication for maintenance therapy with glycolysis inhibitors. Oncotarget. 2014 Sep 30;5:8703-15.

89. Versantvoort CH, Broxterman HJ, Bagrij T, Scheper RJ, Twentyman PR. Regulation by glutathione of drug transport in multidrug-resistant human lung tumour cell lines overexpressing multidrug resistance-associated protein. $\mathrm{Br}$ 
J Cancer. 1995 Jul;72:82-9.

90. Huang Y, Dai Z, Barbacioru C, Sadée W. Cystine-glutamate transporter SLC7A11 in cancer chemosensitivity and chemoresistance. Cancer Res. 2005 Aug 15;65:7446-54. 